\title{
På vej mod en forklaring af magi
}

\author{
Review-artikel af skelsættende bog om magi
}

ANDERS KLOSTERGAARD PETERSEN

\begin{abstract}
ENGLISH ABSTRACT: In recent years, there has been a strong tendency in scholarship to call a moratorium to the use of magic as a valid analytical term. The social-relational nature of the term has made it dubious as a scholarly category. Contrary to this trajectory of scholarship, Jesper Sørensen in his ground-breaking work, A Cognitive Theory of Magic, seeks to revitalise the scholarly use of the concept by translating it into cognitive terms. The review-article gives a thorough presentation of the book emphasising how it helps us to see time-honoured problems within the study of religion and anthropology from an entirely new perspective. At the same time, the book persuasively documents how acquaintance with cognitive theory is also indispensable to scholars working mainly with textual interpretation. Despite criticism in particular pertaining to Jesper Sørensen's discussion of various forms of Protestantism, the book is recommended as a new classic within the study of religion.
\end{abstract}

DANSK RESUME: Jesper Sørensens bog, A Cognitive Theory of Magic, er et banebrydende arbejde i nyere religionsvidenskab og antropologi. Mens der de seneste år $i$ forskningen har været en stærk tendens til at opgive magibegrebet ud fra en tanke om, at det alene er en social-relationel kategori, der bruges som led i egen identitetskonstruktion til at afvise de former for kult, man ikke selv bryder sig om, går Jesper Sørensen en anden vej. Han genopliver ikke alene magibegrebet ved at indsætte det $i$ en kognitionsteoretisk ramme, men han dokumenterer også overbevisende, hvorfor antropologi og religionsvidenskab ikke kan være kategorien foruden. Samtidig peger bogen på en række løsninger af klassiske problemer i religionsvidenskab og antropologi. Review-artiklen giver en udførlig præsentation af bogen, der ikke alle steder er lige let læsning for folk uden for det kognitionsteoretiske formskærerlaug. Bogen viser imidlertid tydeligt, hvorfor de af os, som primært arbejder med tekstanalyse, historiske rekonstruktioner eller religionssociologi og religionsfilosofi, ikke kan ignorere den stadig mere ekspanderende kognitionsteoretiske religionsvidenskab. 
KEYWORDS: Magic; Theory of Magic; Cognitive Theory; Agency; Iconicity; Indexicality; Metaphor; Metonymy.

Jesper sørensen, A Cognitive Theory of Magic, Alta Mira, Lanham, MD, 2007, 218 sider, \$29,95 (paperback)

Man møder undertiden i religionshistoriske kredse skepsis over for kognitionsteoretiske tilgange til studiet af religion. Ser man bort fra de elementer i denne skepsis, som alene skyldes en teoriforskrækket tradition, bunder den også i en legitim usikkerhed over for, hvad kognitionsvidenskab de facto kan tilføre en mere tekstorienteret forskning. Kan den overhovedet bidrage til udlægning og forståelse af tekster, eller befinder den sig ikke snarere på et andet niveau, der ligger langt fra tekstfortolkningen, uanset hvor interessant den så i øvrigt måtte være? Hvordan komme fra spørgsmålet om grundlæggende kognitive mekanismer til deres konkrete anvendelse i historisk, sofistikerede kulturelle manifestationer?

Jesper Sørensens (JS) reviderede ph.d.-afhandling - alle bogens øvrige fortjenester i første omgang ufortalt - gør det én gang for alle umuligt for religionshistorikere at ignorere kognitionsvidenskabens bidrag til religionsvidenskaben. Uden at forholde sig eksplicit til temaet dokumenterer bogen overbevisende, hvordan kognitionsteori også kan bruges i arbejdet med tekster, som vi traditionelt har haft vanskeligt ved at få hold på. Ja, mere end det. Den vover at tage livtag med det måske mest centrale spørgsmål overhovedet, når det gælder forståelsen af religion: Hvordan skal vi tænke og forklare magi, dvs. spørgsmålet om hvorledes man gennem bestemte og ikke-almindelige handlinger med uklar kausal virkning kan forandre bestemte personers, genstandes, handlingers og begivenheders status og væsen?

Det centrale problem drejer sig ikke så meget om oversættelsen fra et kontaktunivers til et andet, men i højere grad om hvordan vi inden for vort kontaktunivers er i stand til at forklare brugen af handlinger, der for en moderne rationalitet fremstår som irrationelle. Hvis ikke man blot skal afvise magi og subsidiært religion, der selv i dens mest subtile former dårligt kan undvære magiske forestillinger, som udtryk for intellektuel uformåenhed, kræver det en forklaring - og selv hvis man reducerer religiøsitet til kognitiv vankundighed, står man fortsat med problemet, hvorfor mennesker, der burde vide bedre, fremturer i deres ufornuft. Magi og religion er som bekendt ikke kun fortidige fænomener. Hvad er det med andre ord, der i bestemte situationer gør det attraktivt at være religiøs og at ty til handlinger, som man $i$ andre sammenhænge ikke ville drømme om at hengive sig til? Hvad enten der - trods alle både eksterne og interne forskelle - er tale om zander, nutidige folkekirkekristne eller antikke romere, synes der at være en evne til at skelne mellem, hvornår man handler religiøst og hvornår man ikke gør det - uanset om den evne er gjort til genstand for eksplicit refleksion eller ej. Som Jonathan Z. Smith i en berømt artikel lakonisk bemærker, har man til dags dato endnu ikke set en bo-roromand, som i religiøse sammenhænge er kendt for at identificere sig med en papegøje, forsøge at parre sig med en hunpapegøje. Trobriander 
formår uproblematisk at sondre mellem dyrkning af jorden og magiske handlinger, der omkranser deres havedyrkning. Vi er derfor som religionsvidenskablere nødt til at forklare dels, hvorfor mennesker i bestemte kontekster vælger at tænke og handle religiøst, når de kunne have valgt anderledes, dels hvad rationalet bag denne tænkning er. Hvordan er den relateret til menneskelig kognition i almindelighed?

Bogens fokus er magi, men dens rækkevidde er betydeligt bredere, fordi den ved så direkte at rejse magispørgsmålet og forstå magi som et uomgængeligt religiøst element ikke kan undgå at stille spørgsmålet om religion overhovedet. Magi er måske nok religion sat på spidsen, men omvendt kommer ingen religion uden om at rumme magiske dimensioner, hvis der fortsat skal være tale om religion. Selvfølgelig er der forskel på at stikke nåle i en dukke for at skade sin modstander og at abonnere på en forestilling om, at en gud i en eller anden forstand er i stand til at meddele sig ind i den menneskelige verden, men der er også en betydelig grad af lighed. Hvis religion - uanset hvad den i øvrigt måtte være - først og fremmest vedrører forestillinger om transempiriske magter, der kan gribe ind i og forandre, hvad der intuitivt opfattes som den empirisk tilgængelige verden, drejer problemkredsen sig netop om religionens og i særdeleshed ritualets magiske dimension. Derfor er det afgørende, at man i religionsforskningen kan aflægge regnskab for dette aspekt; men det er, som vi ved fra forskningshistorien, også det notorisk mest vanskelige spørgsmål i religionsstudiet.

JS fortjener megen ros for sit mod til overhovedet at stille dette spørgsmål; men måden, han gør det på og ikke mindst de svar, han når frem til, bringer os også videre. Man er efter at have læst bogen ikke alene blevet klogere på magi, men på religion generelt. Ja, man har fået et sprog og en teoridannelse, som i vid udstrækning sætter os i stand til at tale og tænke om det, som vi gennem mange år ikke rigtig har kunnet røre ved, fordi vi ikke var i stand til at konceptualisere det specifikt 'magiske' inden for rammerne af det videnskabelige kontaktunivers. Jeg tror derfor ikke, at jeg som anmelder tager munden for fuld, når jeg hævder, at der er tale om et skelsættende arbejde inden for religionsvidenskab, antropologi og kognitionsvidenskab. Hvis man i fremtiden vil arbejde seriøst med religion og magi, kommer man ikke uden om JS's bog - parentetisk bemærket kan man i vor lokale sammenhæng glæde sig over, at det er Århus-kolleger som Armin Geertz og Jeppe Sinding Jensen, der har været åndelige faddere til denne oprindeligt i Århus indleverede Ph.d.-afhandling. Bogens ambitionsniveau, dens centrale problemfelt og dens teoretiske tilgang til magispørgsmålet begrunder en udførlig præsentation.

Uden at der i øvrigt er nogen direkte sammenhæng, deler JS's bog skæbne med en anden nylig Århus-afhandling, nemlig Jeppe Sinding Jensens The Study of Religion in a New Key (2003). Fælles for de to bøger er, at de vælger at revitalisere begreber, som man i dagsordensættende kredse i moderne religionsvidenskab på grund af deres ideologisk belastede fortid har lagt for had og derfor opgivet. Men hvorfor smide barnet ud med badevandet og opfinde nye begreber, hvis de fænomener, begreberne traditionelt har henvist til, fortsat eksisterer? Så er det mere meningsfuldt med de to forfattere at omdefinere begreberne (henholdsvis religionsfænomenologi og magi) og fravriste dem 
deres problematiske fortid, uden at man behøver at opgive dem. Det er netop, hvad JS gør. Selvfølgelig har magibegrebet haft en blakket fortid, hvor det ikke mindst har tjent som en socialt-relationel kategori til at spidde de former for religion og religiøsitet, man ikke brød sig om, hvad enten det var i forskningen eller i bestemte religiøse kredse: "Min gudstjeneste er din magi, og omvendt." Men derved overser man, at der er tale om et både hævdvundet og velegnet begreb til at sætte det specifikt religiøse på kortform: "Magic is about changing the state or essence of persons, objects, acts, and events through certain special and non-trivial kinds of actions with opaque causal mediation" (32). Hvis man forstår begrebets heuristiske og modelagtige karakter, som JS tentativt definerer det, er det ikke alene en uproblematisk kategori, men et væsentligt greb til forståelse af religion generelt.

Ud over en kortfattet indledning (kap. 1) og et fælles emne- og forfatterregister består den prisværdigt korte og koncist formulerede fremstilling (færre end 190 sider og ganske få fejl) af seks kapitler (kap. 2-7). I kap. 2 kridter JS banen for sin egen forståelse af ved at gå i clinch med den tidligere forskningstradition, som han pædagogisk overskueligt og sagligt indlysende inddeler i fire hovedstrømninger: den intellektualistiske repræsenteret ved Frazer og Tylor og i nyere tid ved Jarvie \& Agassi; den symbolorienterede, hvis repræsentanter befinder sig inden for en durkheimiansk tradition præget af navne som Hubert \& Mauss og Evans-Pritchard; en pragmatisk og performativ forklaring på magi domineret af navne som Malinowski (der imidlertid af mange placeres i den fjerde kategori) og i nyere tid Tambiah (hvilket ikke har udelukket Tambiah fra at kritisere Malinowskis magiopfattelse); og endelig en emotionalistisk tradition med så forskellige forfægtere som Marett, Lévy-Bruhl og Freud.

JS kunne meget vel, som det ofte sker i forskningshistoriske fremstillinger, hvor man dels savner ydmyghed over for den tradition, man selv står i forlængelse af, dels ikke har erkendt sin egen positions endelighed, have gjort sig munter over den tidligere forskning; men han handler mere frugtbart. Vel lyder der berettiget kritik mod tidligere positioner, men det bærende i fremstillingen er fremhævelsen af de elementer, som de forskellige forskningshistoriske strømninger hver især har formået at favne, og som også er afgørende for en moderne magiforståelse. Det er da også tankevækkende at se, hvordan bærende elementer hos Tylor og Frazer har afgørende betydning i JS's magiforståelse. Ja faktisk er det ikke forkert at hævde, at Frazers tanke om lighed og berøring som de to centrale principper i al magi også udgør kernen i JS’s opfattelse, hvor lighed og berøring gennem en semiotisk ramme først transformeres til sproglige figurer som metafor og metonymi, for siden at blive identificeret med ikon og indeks i en peircesk tegnforståelse. Intellektualisterne prises for at have forstået, at de kognitive mekanismer, der ligger bag magisk tænkning og handling, er universelle og generelle og derfor ikke kan reduceres til magi og religion. De har også taget magiens instrumentelle side alvorligt, dvs. at magi af udøverne de facto forstås som et forsøg på at ændre omverdenen. Intellektualisterne kommer imidlertid til kort, når de identificerer magiske forestillinger med propositionelt formulerede tanker, dvs. at magiske handlinger bygger på eksplicitte trosstrukturer. Netop derfor er de iflg. JS ikke i stand 
til at begribe, hvordan udøvere uproblematisk formår at skelne magiske og rituelle handlinger fra hverdagshandlinger, ligesom de heller ikke kan give en plausibel forklaring på, hvorfor mennesker fortsat tyer til magi/religiøse handlinger. Man er med andre ord nødt til at forstå, at selv om magisk handling bygger på basale kognitive mekanismer, sker det i relation til en specifik rituel ramme, som man er nødt til at medtænke, hvis man skal forstå magi.

Omvendt ser symbolisterne, at der ikke er nogen ligefrem forbindelse mellem udøvernes intentioner og det, der finder sted i den magiske handling, ligesom de har blik for handlingens særlige rituelle karakter. Yderligere har de sans for, hvordan den er snævert bundet til den kulturelle kontekst, som den udfoldes inden for, og som bidrager til at give den mening. De mangler imidlertid sans for handlingens instrumentelle dimensioner, ligesom de i deres forsøg på at gøre magi til meningsfuld praksis ved at tolke den som symbolsk udtryk for samfundets grundværdier, tilsidesætter de magiske udøveres egne forestillinger og intentioner.

Parallelt med en intellektualistisk tilgang fremhæver tilhængere af en pragmatisk og performativ magiforståelse magiens instrumentelle side, men pointerer i modsætning til intellektualisterne, hvordan magi udøves i specifikke sammenhænge med bestemte mål for øje. Magi er en særlig type kommunikation, som derfor ikke kan reduceres til en bestemt 'primitiv' måde at tænke på. JS's kritik mod denne tilgang lyder, at den i sin fremhævelse af ritual og magi som en særlig type handling er tilbøjelig til at ophøje ritualet til en bestemt æstetisk eller ekspressiv kategori, hvorved den - trods egne intentioner - alligevel ender med at underkende magiens instrumentelle intentioner, ligesom den i sit fokus på talehandlingsteori dels undervurderer anden tegnbrug, dels ignorerer, at man i magiske ritualer ofte anvender meningsløs tale som del af kommunikationen. Magi kan derfor ikke reduceres til propositionelt sprog, dvs. til domsudsagn om verden.

Den emotionalistiske tilgang har sin styrke i anerkendelsen af magiens sammenhæng med et affektivt aspekt. Magi finder ikke sted i et følelsesmæssigt tomrum, men er ofte ledsaget af stærke følelser, ligesom den hyppigt fremkaldes af situationer med et udtalt følelsesmæssigt indhold som fx had og begær. Den emotionalistiske tilgang ligner den symbolorienterede forståelse ved at forklare magi på en måde, der står i modsætning til udøvernes egne forklaringer. I modsætning til symbolisterne forsøger den imidlertid ikke at forstå fænomenet ud fra tanken om, at den magiske handling bærer en skjult symbolsk betydning, som spejler det pågældende samfunds grundlæggende værdier. Påstanden er i stedet, at magi skal forklares i sammenhæng med bestemte menneskelige følelsesmæssige dispositioner eller situationer. JS fremhæver heroverfor, at følelser ikke i sig selv kan forklare den universelle brug af magi eller de specifikke kognitive processer involveret i magiske handlinger, men han medgiver emotionalisterne deres betoning af det affektive niveau og pointerer, at han selv opfatter sin bog som et bidrag til "the very modest emphasis on the role of emotions in establishing and strengthening conceptual connections found in magical rituals" (s. 28). 
I de følgende fire kapitler indoptages de forskellige positive aspekter, som JS finder i de fire forskningshistoriske hovedstrømninger, i en kognitivt funderet teori om magi. Da der i denne del af bogen er tale om en meget teknisk og teoritung redegørelse, kræver det langsom og årvågen læsning, hvis ikke man som læser skal hægtes af. Det skyldes også, at indbyrdes forskellige kognitive tilgange, der her skildres i primær relation til bogens genstandsområde i stærkt kondenseret form, bringes i samtale med hinanden. Den ordknappe redegørelse har en forbilledlig analytisk klarhed, men der betales også en pris for den puristiske fremstilling. Nogle steder kunne man godt have ønsket en lidt mere verbos udfoldelse, ligesom yderligere eksempler ville hjælpe læseren.

Kap. 3 lægger det kognitionsteoretiske fundament for den efterfølgende fremstilling. Det kredser om tre centrale felter. Det første handler om basal menneskelig kategorisering, og JS følger her den såkaldt domænespecifikke forståelse, hvor menneskelig kognition ikke opfattes som et kohærent system, der benytter sig af generelle procedurer i forholdet til omverdenen, men derimod af en række systemer, der bringes i anvendelse i relation til bestemte domæner. Tanken er, at mennesker på et prækulturelt niveau kategoriserer verden i relation til specifikke domæner, der styrer menneskets forventninger om kausal adfærd og grundlæggende egenskaber. På tværs af tid og rum nærer mennesker intuitive forestillinger om fx forskellen mellem livløse og levende genstande. Mens levende genstande tilskrives intentionalitet, kan livløse genstande kun bevæge sig under forudsætning af påvirkning fra ydre kilder. Det næste punkt drejer sig om sammenhængen mellem det prækulturelle kognitive og det kulturelle niveau, eftersom forbindelsen mellem begrebslige domæner og kulturelle modeller udgør et grundlæggende element i al magi. Påstanden er, at konceptualisering udgør en bro mellem kulturelt specifikke, semiotiske systemer og kognitive begrænsninger på selve kategoriseringen. Her ligger en vigtig stillingtagen, fordi JS i modsætning til stærke strømninger inden for kognitionsvidenskaben ikke opgiver kulturbegrebet, men derimod tilkender det kulturelle niveau betydning og frugtbart forsøger at forstå sammenhængene mellem de kulturelle og kognitive niveauer. Som tredje punkt introduceres blending-teori, der gøres til omdrejningspunkt for at forstå, hvad der er på spil i repræsentationer i magiske handlinger. Blending er den tekniske betegnelse for sammenføring af elementer fra forskellige domæner som i fx metaforer som 'livet er en rejse', men blending begrænser sig ikke kun til sproglige figurer. Vi kender det som et centralt rituelt element. Man kan fx tænke på huichol-indianernes rituelt gennemspillede valfart, hvor shamanens flytning af bomuldstotter fra et hjortegevir til hans tromme er et ikonisk og indeksikalt udtryk for børnenes valfart til det område, som huicholerne i deres mytologi hævder at stamme fra. Først på et senere tidspunkt, når børnene er kommet til skels år og alder, kan de selv deltage i den faktiske valfart til vulkanen Lehunar, som ikke kun er en mytisk størrelse, men også en konkret geografisk lokalitet. På denne måde finder en rituel blending sted, hvor bevælgelsen af bomuldstotterne modsvarer den rejse, børnene på et senere tidspunkt selv skal foretage. Man kan også tænke på syndebukkeritualet i israelitisk religion, hvor en buk på forsoningsdagen 
blev drevet ud i ørkenen, efter at folkets synder var blevet lagt på den. For det første finder der en overførelse af folkets synder på bukken sted. Dernæst er bukkens bevægelse ud i ørkenen et ikonisk og indeksikalt udtryk for, at folkets synder fjernes fra Israels midte. Eksemplerne på blending i ritualsammenhæng er legio.

Betydningen af blending ligger først og fremmest i dannelsen af ny betydning eller nye strukturer, der opstår ved, at to oprindeligt adskilte felter (såkaldte input spaces) sammenstilles i et blended space. Ud over disse tre rum taler man også om generic space, hvor de abstrakte egenskaber, der overhovedet muliggør dannelsen af delvist parallelle forbindere (counterpart connectors) mellem elementerne i input spaces, repræsenteres. Tanken er, at to input-rum for at kunne blendes nødvendigvis må dele visse strukturer. Generic space kan være fx billedskemaer, psykologisk essentialisme eller abstrakte størrelser som agens, handling og objekt - alle centrale elementer i magiske repræsentationer. Det er i denne sammenhæng, basal kognitiv kategorisering har stor betydning for magiforståelsen, fordi de elementer, som hører generic space til, hidrører fra de prækulturelle kognitive processer, som ligger bag kategoriseringerne. I modsætning til generic space gælder det for counterpart connectors, at de er begrænset af pragmatiske og begrebslige træk som fx motivation, relevans og konvention. Når det gælder magiske ritualer, er der tre typer counterpart connectors, som i vid udstrækning er identiske med Frazers tale om lighed og berøring som de to centrale principper i al magi: 1) forbindere baseret på identitet og metonymisk udvidelse og muliggjort af psykologisk essentialisme i generic space, og semiotisk udtrykt i brugen af indekser; 2) forbindere funderet på metaforisk, analogisk og lighedsbaseret overførelse muliggjort af billedskemaer, kraft-dynamik, fundamentalkategorisering og erfaringsmæssig korrelation, og udtrykt i brug af ikoner; 3) rolleværdi-forbindere bygget på formalt symbolske (altså arbitrære og konventionelle), funktionelt ikoniske og essentielt indeksikale relationer. Den sidste type omfatter noget så væsentligt, som at personer kan optræde i bestemte roller som fx præst. 
Den basale blending-figur

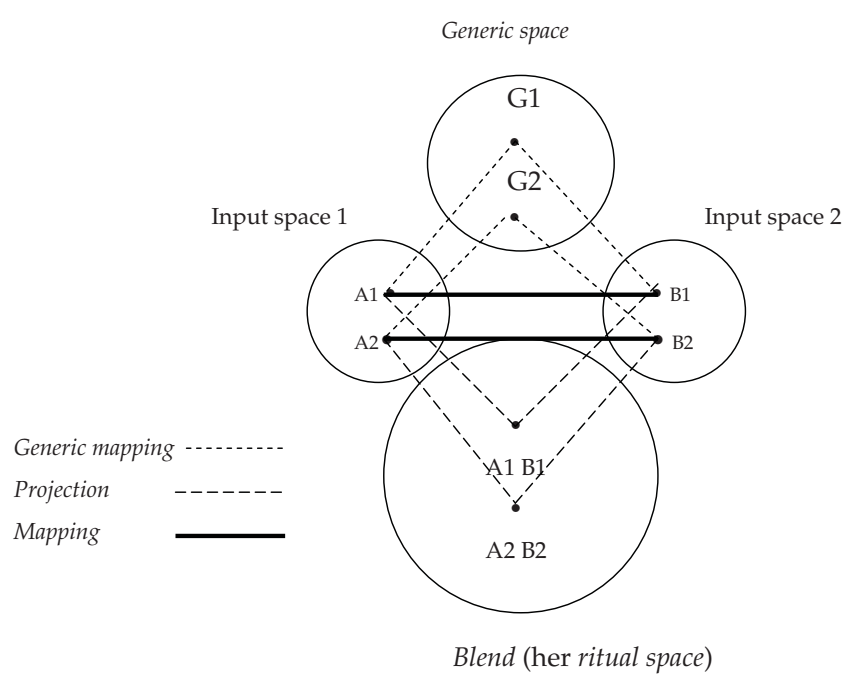

Det er en hovedpointe i bogen, at konceptuel blending udgør et grundelement i al magi, men at blending-teori er i sig selv ikke tilstrækkelig til at udvikle en magiteori. Først og fremmest må blendet indeholde et element af magisk agens, hvis ritualet skal kunne tilskrives virkning. Derfor suppleres blending-teorien på flere punkter i kap. 4, hvor JS dels pointerer, at magiske ritualer reflekterer et temporært blendet rum bestående af elementer, der hidrører fra enten et helligt eller et profant domæne, dels diskuterer tre hovedkategorier for, hvordan magiske ritualer kan tilskrives agens, dvs. det element, som overhovedet gør dem rituelt virkningsfulde. Det kan ske ved, at enten agenten (fx en shaman), objektet ( $f x$ nadverelementer) eller handlingen ( $f x$ brug af bestemte formularer) forlenes med en særlig form for magisk virkning. Ofte vil man i konkrete ritualer finde, at forskellige agenstyper indgår i samme ritual. Når det gælder forståelsen af forholdet mellem hellig-profan, bygger JS videre på en kognitivt funderet opfattelse i forlængelse af Pascal Boyer. "Hellig" betegner et begrebsligt domæne, som indeholder begreber, rammer, idealiserede kognitive modeller og viden, som af deltagerne tilskrives særlig betydning, fordi de bryder med intuitivt forståede ontologier, indlejres i kosmogonier og kosmologier, og fortolkes som del af en transempirisk verden, som det kræver særlige handlinger at komme i berøring med (s. 63). Den meget tekniske diskussion blødes i dette kapitel op af tre ritualeksempler, der illustrerer frugtbarheden i den teoretiske tilgang og gør det klart for læseren, hvor meget man vinder ved de teoretiske anstrengelser i forhold til konkrete analyser. I slutningen af kapitlet drøftes det meget omfattende og forskningshistorisk klassiske spørgsmål om sprogets betydning i magi og ritual. JS betoner blandt andet, hvordan sprog kan bruges som en rituel markør og som led i konstruktionen af det rituelle rum, fx gennem brug af propositionelt meningsløst sprog, som vi kender fra hokuspokus, simsalabim, etc. Han fremhæver også sammenhængen mellem sprogbrug og socialt ejerskab. Esoterisk og 
gådefuldt magisk sprog kan sætte skel mellem mennesker: dem, der gennem kodekendskab har adgang til de virkemidler, som kan etablere forbindelse til den transempiriske verden, og dem, der er afhængige af den første gruppe for at få adgang til den anden verden.

I kap. 5, der er afhandlingens mest omfattende, præsenteres en typologi over magiske handlinger koncentreret om begreberne transformation og manipulation. Det er Frazers to magiske grundprincipper, berøring og lighed, der udgør det kriteriologiske omdrejningspunkt, men begreberne er her indsat i en kognitionsteoretisk og semiotisk ramme, ligesom Frazers forståelse er udvidet på et væsentligt punkt. Hvor Frazer kun diskuterede retrospektiv berøring som del af magi ( $f x$ brug af en persons negle til at skade den pågældende ud fra princippet om, at neglene på et tidspunkt har været $\mathrm{i}$ berøring med personen), inkluderer JS også den prospektive berøring (fx overførelse af magisk agens gennem nadverelementer med henblik på en fremtidig virkning, fx at den kristne kan fremstår som ren) som centralt magisk element. I stedet for at se lighed (metafor/ikon) og berøring (metonymi/indeks) som specifikke former for magisk handling er tanken her ud fra et blending-perspektiv, at de skal ses som forskellige måder til at etablere forbindelser mellem forskellige mentale domæner. Der er grundlæggende to typer (s. 96f), hvilket igen ikke udelukker, at konkrete ritualer ofte vil rumme træk fra begge prototyper: 1) transformative magiske handlinger, der overfører væsenskvaliteter (essens) fra elementer tilhørende ét domæne til elementer i et andet (fx nadver); 2) manipulative magiske handlinger, som forandrer elementer inden for ét domæne gennem manipulation af elementer (billedskema) inden for et andet domæne (fx brug af dukker i voodoo). For begge typer gælder, at de findes i både retrospektive og prospektive former. Ud over at udvide Frazers typologi med kategorien prospektiv berøring er JS’s typologi også gennem dens skelnen mellem transformativ og manipulativ magi i stand til at sondre mellem retrospektiv berøring og lighed, som det på baggrund af Frazers terminologi kan være vanskeligt at differentiere klart imellem. Parallelt med kap. 3 dokumenterer dette kapitel, hvordan magisk tænkning bygger på basale kognitive operationer. Gennem essenstilskrivning og brug af billedskemaer styrkes den magiske handlings ikoniske og indeksikale aspekter på bekostning af konventionel symbolsk kommunikation. Der finder en afsymbolisering sted, som er helt afgørende for ritualisternes forståelse af den rituelle kommunikation. Det er denne anderledes og kognitivt mere grundlæggende form for kommunikation, der gør det muligt for udøverne at skabe nye begrebslige forbindelser, som fremprovokerer nye symbolske fortolkninger og giver grundlag for vurderinger af ritualets magiske effekt:

By removing ritual elements from their everyday interpretative frame-in which they have conventional meanings according to symbolic interrelations-their direct perceptual qualities and ascribed essentialist assumptions are foregrounded, allowing for the manipulation of these basic aspects of the ritual frame (s. 137). 
Det er en meget vigtig pointe, fordi det ofte er på dette punkt, man i forskningshistorien er gerådet i problemer i forhold til at forstå magi. Man har identificeret magisk tegnbrug med eksplicitte repræsentationer, der forudsætter, at de magiske udøveres handlinger skal forstås som udtryk for et sammenhængende, propositionelt og symbolsk forklarligt verdenssyn, der kan aflægge regnskab for det kausale forhold mellem den prærituelle situation, den rituelle handling og den situation, som den hævdes at effektuere.

Dermed har JS fået fremhævet, hvad han også anførte i sin kritik af den intellektualistiske tilgang, at den ikke i tilstrækkelig grad har sans for, at magi og ritual finder sted inden for en bestemt ramme, som sætter grænser for den kognitive aktivitet. Det er netop karakteristisk for udøvere af magi, at deres repræsentationer af magiske handlinger og elementer har en indeksikal og ikonisk, implicit og ikke-propositionel karakter, og det er denne kombination, der gør det muligt for dem at tilskrive handlingerne og elementerne magisk virkning. Hvordan det kan lade sig gøre, udfoldes yderligere i kap. 6, som diskuterer forholdet mellem magiske repræsentationer og rituel kontekst. Magi bygger på grundlæggende kognitive mekanismer, men de bringes til udfoldelse i en rituelt defineret ramme. Skal man forstå, hvordan mennesker kan tilskrive bestemte handlinger magisk agens, må man derfor have fat i det særlige ved denne ramme. Magiske handlinger er, hævder JS, helt afhængige af mentale og kulturelle repræsentationer knyttet til to sæt relationer: 1) forbindelsen mellem den magiske handling og den situation, der gik umiddelbart forud for ritualet som fx sygdom eller elendig høst (diagnosis); 2) forbindelsen mellem den magiske handling og den situation, den resulterer i (prognosis) (s. 141). Samlet udgør disse tre: den magiske handling selv, dens diagnosis og dens prognosis, en fælles begivenhedsramme, en event frame. Det er derfor oplagt dels at drøfte den særlige form for kausalitet, der er på spil i magiske handlinger, dels at diskutere relationen mellem udøvernes intentionalitet og den handling, de er involveret i. I relation til det sidste punkt er det åbenbart i ritualisering, at forbindelsen mellem intentionalitet og faktiske magiske handlinger er brudt. Der er ikke nogen direkte sammenhæng mellem fx at sige "Sesam, luk dig op!" og at opnå et bestemt handlingsresultat i modsætning til fx at sætte sin nøgle i låsen for efterfølgende at åbne døren. Det gælder for ritualisering, at udøvernes intentioner retter sig mod hele den rituelle sekvens (fx at opnå magisk kraft gennem essensoverførelse), mens de enkelte rituelle led i vid udstrækning er intentionelt underdeterminerede. Det rejser spørgsmålet om rituel kausalitet, hvor det også er iøjnefaldende, at intuitive forventninger om kausale forbindelser sprænges til fordel for en anden type kausal relation mellem handlingerne i det rituelt blendede rum og den prærituelle situation og den situation, ritualet fuldbyrder. Man får normalt ikke tilgivelse ved at spise en kiks og drikke en slurk vin! Kendte elementer fra en given kulturs symbolsystem bliver gennem ritualisering afsymboliseret og får i stedet betydning i relation til mere basale, prækulturelle kognitive operationer som fx essenstilskrivning og billedoverførelse. De mister ikke derved deres symbolske betydning, men den overdetermineres af en mere fundamental form for kommunikation. JS nævner selv eksemplet med at sværge med 
en hånd lagt på bibelen og ikke på en telefonbog. Det gælder således, at kausale formodninger om sammenhængene mellem prærituel situation, rituelle handlinger og den situation, ritualet fører til, svækkes til fordel for symbolsk svagere fundamentalkognitive forestillinger bygget på ikoniske og indeksikale relationer. Det er denne anderledeshed i forhold til gængse forestillinger om kausalitet og intentionalitet, der muliggør, at den magiske handling kan tilskrives effekt. Fravær af normalkausalitet og intentionalitet gør det oplagt i udøvernes repræsentationer at forklare handlingen ud fra forestillinger om, at der må være andre intentionaliteter på spil.

I kapitlets sidste del søger JS at udarbejde en typologi over forskellige magiske ritualers formål med udgangspunkt i en sammenstilling af forskellige rituelle begivenhedsrammer med de billedskematiske strukturer indeholdt i de ritualiserede handlinger. Også her brydes ny jord, men desværre i en noget lapidarisk form. Der er en gammel tradition for at udvikle sådanne ritualtypologier, men de er sædvanligvis organiseret ud fra spørgsmålet om, hvorvidt et givet ritual skaber en ny værenssituation (progression), afværger en potentiel krise (protektion), genskaber en tidligere ødelagt situation (restauration) etc. Derved bliver man blot ikke klogere på, hvordan det rituelle formål relaterer sig til de repræsentationer, der knytter sig til grundlæggende aspekter i udførelsen af de enkelte rituelle handlingssekvenser. Her forsøger JS - efter først at have indført en mere forskningshistorisk hævdvunden sondring mellem prospektiv og retrospektiv magi - med udgangspunkt i den fundamentale billedskematiske struktur, container, at udvikle en typologi over rituelle formål. Det giver god mening, fordi containerskemaet spiller en væsentlig rolle i repræsentationer knyttet til mange ritualer. Det står imidlertid ikke helt klart for mig, om JS mener, at det gælder samtlige eller blot flertallet af religiøse ritualer. Som skema er containere defineret dels ved indhold, dels ved grænser, der kan overskrides ved, at noget enten trænger ind eller ud. Containerskemaet kombineret med andre skemaer, fortrinsvis et trajektionsskema, der angiver forskellige elementers forhold til containeren, er et godt typologisk udgangspunkt. Man overfører eksempelvis essens fra én container til en anden ( $f x$ nadver), eller man fjerner uønskede elementer fra bestemte ritualiserede rum (fx en ritualiseret krop i eksorcisme). De billedskematiske strukturer er værdineutrale. Der er ikke noget, som betinger, at en essensoverførelse har positiv værdi. Det er kontekstafhængigt både i relation til rituel og kulturel ramme, hvilken værdi anvendelse af en given billedstruktur tilskrives. Frem for at søge den rituelle betydning i et propositionelt, symbolsk univers fremanalyseret gennem en symbolisering af et givet ritual skal dets mening i stedet findes i relationen mellem billedskemaer og rituel begivenhedsramme. Det er rigtig godt tænkt; men man kunne have ønsket, at redegørelsen for hele denne typologi var blevet udfoldet noget mere end blot de fem sider, der er blevet den til del (s. 165-69).

Bogens afsluttende kapitel stiller i forlængelse af de fire forudgående kapitler de to helt grundlæggende spørgsmål: Hvilke kognitive processer og begrænsninger øver indflydelse på repræsentationer af magisk handlen, og hvilke faktorer og parametre er til stede i en idealt forestillet udøvers repræsentationer af formålet med den magiske 
handling? Det udfoldes i en model, der samtidig giver lejlighed til at sammenfatte bogens hidtidige resultater og spidsformulere flere af de overordnede pointer. Fx formuleres bogens grundlæggende tese meget prægnant: “by means of ritualisation, culturally specified symbolic meaning and domain-specific causal relations of ritual elements are de-emphasised or even violated in order to forward their inherent essentialist and schematic properties" (s. 175). Denne hypotese giver anledning til den meget væsentlige, afledte påstand, at ritualisternes ( dvs. ritual-deltagerne selv eller nogle af dem) vurderinger af rituelle handlingers mulighed og sandhed er sekundære, symbolske bearbejdelser, der hviler på kulturelle konventioner og diskursive genrer, mens den rituelle brug af ikoniske og indeksikale forbindelser umiddelbart fæstner sig, fordi de bygger på mere grundlæggende kognitive mekanismer knyttet til både domæne-specifik og domæne-generel kategorisering (ibid.). Her får vi ganske enkelt forklaringen på, hvorfor det, som den hidtidige forskning har opfattet som det grundlæggende problem for at forstå magi/religion, nemlig at der ud fra normale kausalitetsog intentionalitetsbegreber ikke kan være en sammenhæng mellem den magiske handling og det ønskede resultat, tilsyneladende er et skinproblem. Magi 'virker' i kraft af de kognitive mekanismer, den i sammenhæng med en rituel ramme 'trigger', og derfor er normale årsags- og intentionsslutninger knyttet til symbolsk, propositionel kommunikation enten sat på stand-by eller placeret som sekundære relationer. Alene denne indsigt er hele bogen værd.

Kapitlets afsluttende del stiller det spørgsmål, som der gennem størstedelen af bogen har hersket nogen uklarhed om (se dog s. 141f), hvad er det præcise forhold mellem magi, ritual og religion? Er magi religion sat på spidsen eller betegner det en særlig form for religiøsitet? Er der forskel på den institutionelle ramme, magi og religion finder sted inden for? Er magi og ritual synonyme, eller betegner magi det specifikt rituelle forstået som ritualets virkekraft, dvs. den rituelle efficacitet? Også her har jeg sympati med JS's forståelse af magi, når han afviser magi som en slags religiøst system, men i stedet fremhæver det som "et konglomerat af mere basale repræsentationer af magisk agens, manipulation og overførelse, som fører til repræsentationer af rituel virkekraft" (s. 177). Mens magi således i udgangspunktet lever af en symbolsk underdeterminering og i forholdet mellem de rituelle handlinger og såvel den prærituelle som den postrituelle situation en tilsidesættelse af normale forestillinger om intentionalitet og kausalitet, kan man udmærket forestille sig magiske ritualer, hvor der blændes op for den symbolske dimension. Det gælder fx mange former for protestantisme, hvor ritualernes symbolske dimension fremhæves på bekostning af den magiske. JS nævner som eksempel en luthersk nadverforståelse; men det havde været mere oplagt her at diskutere en reformert ritualopfattelse, hvor det specifikt magiske søges dekonstrueret gennem en eksklusiv symbolsk forståelse og ikke som i den lutherske tanke, hvor man både vil blæse symbolsk og have magisk mel i munden. Denne pointe giver imidlertid JS lejlighed til en velbegrundet korrektion af Harvey Whitehouses udbredte ide om en rituel kedsomhedseffekt: "Jo mere et ritual gentages, desto mere kedeligt vil det blive for udøverne." Heroverfor hævder JS, at det snarere er symbolsk overdeter- 
minering, som truer ritualers relevans og gør dem magisk overflødige. Tanken er i modsætning til Whitehouse, at det er rituel indsovsethed i en symbolsk kulturel ramme, der gør det vanskeligt for udøverne på et basalkognitivt niveau at tilskrive ritualerne magisk agens. Til gengæld savner JS sans for den modsatrettede bevægelse, som vi kender fra navnlig en række nutidige ortodokse og katolske sammenhænge, hvor den magiske agens er stagneret i former, som det ikke længere er muligt at overtage kulturelt. Her er det en arkaisk, magisk overdeterminering, som i kollision med en moderne kulturel ramme ikke formår at 'trigge' basalkognitive repræsentationer af magisk agens. Det er med andre ord kirkesamfundenes oplevede kultisk-atavistiske karakter, som gør dem til en intellektuel anstødssten for yngre, veluddannede befolkningslag. Samme fænomen kendes også fra folkekirken, hvor det for mange kirkegængere næppe er manglen på magisk agens, der får dem til at vægre sig ved at deltage i nadveren, men snarere oplevelsen af at regredere til en fortidig bevidsthedshorisont indeholdt $i$ et fremmedartet og intellektuelt vanskeligt overtageligt ritual. Hvorom al ting er, ligger der i overvejelser som disse et betydeligt potentiale til supplering af moderne religionssociologiske studier. Vi får en anden, men uomgængelig vinkel på spørgsmål som fx sekularisering. Religionssociologiske kolleger vil her finde en række interessante refleksioner, som man med stort udbytte vil kunne supplere den eksisterende forskningstradition med, fordi den kognitionsvidenskabelige tilgang giver os adgang til at undersøge basale kognitive operationer under de symbolsk formulerede tolkninger, hvorved den også bidrager til at kaste lys over eventuelle spændingsforhold mellem socialt forankrede og legitimerede fortolkninger og mere grundlæggende repræsentationer. Det er selvsagt et centralt religionssociologisk emne, der også siger noget afgørende om den sociale og kulturelle kontekst, forskellige former for religiøsitet kommer til udtryk indenfor.

Efter at have drøftet forholdet mellem basalkognitive repræsentationer og symbolisering går JS over til at diskutere forholdet mellem magi og det institutionaliserede ritual. Her synes jeg imidlertid, at han geråder i problemer gennem introduktion af en historisk model (med umiskendelig lighed med Webers karisma-model, hvilket JS også selv gør opmærksom på), der prioriterer agensbaseret magi over handlings- og objektbaseret magi. Hans fokus på spørgsmålet om magiens innovative kraft er baggrunden for at relatere drøftelsen til en historisk ramme, der vægter karismatiske figurer og dannelsen af nye religiøse bevægelser over mere traditionsbundne former for magi. Det giver måske nok god mening i forhold til konkrete historiske analyser, men det står mig uklart, om JS også vil gøre en parallel prioritering gældende på det kognitive niveau. Magi er helt sikkert en skabende kraft i dannelsen af nye rituelle strukturer og i revitaliseringen af allerede eksisterende (s. 186), men kan også, som JS andre steder gør opmærksom på, have en stærkt konservativ karakter, hvis den tjener til fastholdelse af bestemte systemer som magisk levende for deres udøvere. Denne drøftelse munder ud i en afsluttende overvejelse om forholdet mellem religion og magi, hvor JS i forlængelse af den introducerede Weber-påvirkede historiske model godtgør, hvorfor der traditionelt internt religiøst har været en konfrontation mellem magi og religion. Magi 
som symbolsk underdeterminering og fundamentalkognitiv overdeterminering truer den teologisk elitære kaste, der lever af et eksegetisk, symbolsk 'riverrun'. Hvis magi åbner for adgang til den anden verden på symbolsk underdeterminerede måder, er den del af religionen vanskelig at kontrollere teologisk og derfor farlig. Alternativt til forståelse af magi og religion som to modsatrettede systemer præsenterer JS en dynamisk forklaring på deres indbyrdes relation: "Magic is a general mode of ritual behaviour that, when appearing outside established, authorised and institutionalised religious rituals, prompts the creation of either new systems of beliefs and religious institutions, or provoke a re-evaluation, reflection and possibly change of already established ritual structures" (191). Men samtidig er magi netop også et konstitutivt element i al religion, fordi det betegner det element, som etablerer forbindelserne til den transempiriske verden.

Nogle kunne måske på baggrund af denne panegyriske anmeldelse få det indtryk, at der er tale om en tekstfetischists beretning om sin omvendelse til kognitionsteoretisk religionsvidenskab. Det er ikke tilfældet; men det skulle gerne stå klart, hvorfor jeg mener, at de af os, som primært arbejder med tekstfortolkning, ikke kan være vore kogntionsteoretiske kollegers banebrydende arbejder foruden. Vi får her skænket nye perspektiver og et nyt teoretisk sprog, som sætter os i stand til at forholde os til og delvist besvare en række af de spørgsmål, som det ikke er lykkedes hidtidig religionsforskning at give tilfredsstillende svar på. Vi begynder så småt at blive i stand til at indfri en række af de ambitioner, som altid har været religionsforskningens fornemste mål at forfølge. JS har med sin bog i den sammenhæng ydet religionsvidenskab, antropologi og kognitionsforskning et uvurderligt bidrag - hverken mere eller mindre. Han besvarer ikke fyldestgørende spørgsmålet, hvorfor mennesker i bestemte sammenhænge tyer til magiske/religiøse handlinger, men han giver et meget kvalificeret bud på, hvilke kognitive mekanismer, der ligger bag magiske handlinger, og som gør magi forståelig som strategi i både fortid og nutid. Magi fremtræder måske nok fortsat som et bizart fænomen, men dette til trods bygger magi på de selv samme grundlæggende kognitive mekanismer, som også ligger bag alle andre kulturelle konstruktioner. Det er ikke magisk tænkning per se, der er mærkværdig. Det er sammenstillingen af basale kognitive mekanismer med en rituel ramme, der udfordrer det kontaktunivers, de fleste af os sædvanligvis bevæger os rundt i. Det ville, som det givetvis også fremgår af denne review-artikel, være synd at betegne bogen som en easy reader. Det er den langt fra. Trods alle gode intentioner er den vanskelig at læse uden kendskab til kognitionsteori; men den er uomgængelig i fremtidig religionsvidenskab og samtlige andre discipliner, der interesserer sig for religion, og det lønner sig virkelig at arbejde med den. Den hører til de værker, som man skal bruge tid på at fordøje, men som er tiden værd, fordi de på eminent vis kildrer tanken.

Anders Klostergaard Petersen, lektor Afdeling for Religionsvidenskab, Aarhus Universitet 